\title{
Prospecção de grafita através de métodos geoelétricos: Investigação na região de Pintadas, Bahia.
}

\author{
Batista, L.S. ${ }^{1 ;}$ Freire, A.F.M. ${ }^{1 ;}$ Bijani, R. ${ }^{1}$ \\ ${ }^{1}$ Universidade Federal Fluminense ${ }^{1}$
}

O grafeno é atualmente um dos mais promissores nanomateriais devido às suas excelentes propriedades físico-químicas, mecânicas, térmicas, elétricas e ópticas. Dessa forma, diversas pesquisas envolvendo o grafeno tem sido desenvolvidas recentemente. Esse material não é encontrado na natureza, mas pode ser produzido através da grafita, ocasionando assim um aumento latente na prospecção por este mineral. Existem diversos depósitos de grafita conhecidos no Brasil, em sua maioria nos estados da Bahia e Minas Gerais, o que foi determinante para a escolha da região de Pintadas, na Bahia, como área de estudo. O presente trabalho faz parte de uma colaboração entre a Universidade Federal Fluminense (UFF), a Companhia Baiana de Pesquisa Mineral (CBPM) e a Seequent, com o intuito de, através de métodos geofísicos, aprimorar as informações sobre as reservas de grafita já conhecidas na área de estudo, além de identificar potenciais alvos exploratórios ainda desconhecidos. Por ser um mineral de alta condutividade elétrica, o método geoelétrico torna-se uma importante alternativa. $\mathrm{Na}$ área de estudo, foi realizado pela CBPM um total de cinco linhas de levantamento IP, de um quilometro de comprimento cada e distância entre eletrodos de 25 metros. Além da análise feita por pseudo-seções, foi realizada uma inversão 3D dos dados de corrente elétrica, permitindo inferir sobre o comportamento de possíveis depósitos em subsuperfície. O polígono selecionado para a inversão compreendeu apenas as quatros linhas mais ao sul da região, pois estas apresentavam espaçamento de 250 metros, enquanto a linha mais ao norte foi descartada em função do espaçamento de um quilometro, o que poderia gerar falsas anomalias. Após este controle de qualidade foi realizada a interpretação dos modelos de condutividade e cargabilidade, onde foi possível identificar corpos anômalos na área estudada, tendo sido possível a correlação com o mapeamento geológico de detalhe, realizado pela CBPM. Utilizando as informações em profundidade, geradas pela inversão, foi determinado o mergulho em subsuperfície da ocorrência já conhecida da região, além de ser capaz de identificar possíveis futuros alvos exploratórios, onde assim pode-se realizar furos de sondagem para averiguação dos prospectos. 